\title{
Lone motherhood as a category of practice
}

\section{Vanessa May}

\begin{abstract}
This paper offers a critical examination of the category 'lone mother', which tends to be viewed as an identity category by both 'lay' people and social scientists. This in turn leads to the category 'lone mother' becoming reified, while the socially constructed nature of it remains hidden. The aim of this paper is to find a way of analyzing the lives of lone mothers without making totalizing claims about these women as individuals, but at the same time without depoliticizing the category 'lone mother'. I argue that adopting Young's (1995), concept of 'serial collectivity' in the study of lone motherhood would enable social scientists to avoid positing that 'lone motherhood' is a unified category or the basis of self-understanding, while at the same time being able to make pragmatic political claims regarding the inequalities that lone mothers face. Furthermore, this paper argues for studying 'lone motherhood' as a category of practice, focusing on how the category is defined, by whom, and to what ends, and the effects this has on the lives of 'lone mothers'.
\end{abstract}

\section{Introduction}

When studying lone motherhood it is customary to utilize the category 'lone mother' and to apply it to the individuals whose lives are the focus of study. This seems straightforward enough. The argument put forward in this paper is that despite some pressing political reasons for continuing to hold on to a notion of 'lone mothers' as a group who face important social and economic inequalities, we cannot assume that lone motherhood is experienced as a basis for identity nor that lone mothers constitute a self-defined group.

Furthermore, I argue for the need to distinguish between categories of practice and categories of analysis (Brubaker and Cooper, 2000) when studying lone motherhood in order to highlight the socially constructed nature of this category. While some scholars have problematized how for example rightwing politicians have defined lone motherhood in debates over family values (eg, McIntosh, 1996; Phoenix, 1996; Roseneil and Mann, 1996), few have questioned the actual existence of the category - with the notable exception of Blackwell Publishing Inc., 9600 Garsington Road, Oxford OX4 2DQ, UK and 350 Main Street, Malden, 02148, USA. 
Duncan and Edwards (1999). I explore what could be gained from studying lone motherhood from a more critical perspective by examining the category 'lone motherhood' itself.

I have elsewhere argued that adopting biographical methods can be fruitful in trying to gain new perspectives on the phenomenon 'lone motherhood' (May, 2001; May, 2004a; May, 2004b). Instead of the usual procedure of interpreting a woman's life or identity through the homogenizing, totalizing and (at times) oppressive lens of lone motherhood, a biographical approach allows the researcher to examine the place of lone motherhood in a woman's selfunderstanding. This argument is in the present paper developed further to encompass three aspects: first, how the category 'lone mother' is constructed, by whom, and to what ends; second, how lone mothers themselves relate to the category 'lone mother'; and third, the degree to which the category 'lone mother' acts as a basis of a sense of collectivity or groupness. But first, I turn to examine why the category 'lone mother' needs to be examined critically.

\section{The effects of categorizing 'lone mothers'}

This paper is based on the premise that it is important to examine the category 'lone motherhood' critically because categorization has real effects in the lives of people, and categories that are defined as somehow lacking or as counternormative tend to have negative effects.

Creating categories is what we humans do both consciously and unconsciously in order to understand the complex world around us (Lakoff and Johnson, 1999; Lakoff, 1987). Through language (words, concepts, theories) we order, make sense of, and provide labels for things, people and experiences, and we tend to take these everyday understandings of the world for granted (Berger and Luckmann, 1966). These categories do not however correspond directly to a reality 'out there' but are rather the product of human embodied reason (Lakoff and Johson, 1999). For example, the category 'family' does not exist in and of itself, independent of our categorization. Yet for most people, it feels natural to think of 'family' as a thing that exists 'out there'.

We understand categories in terms of prototypes that are seen to represent that category (or rather, the inherent property that defines the category) in its purest form (Lakoff and Johnson, 2003: 122). The borders of categories tend however to be porous rather than rigid, which means that non-prototypical examples of a category that are deemed to be sufficiently close to the prototype fall within the category (Lakoff and Johnson, 2003: 122-4). So, for example, even though in contemporary Western cultures the category 'family' is based on a prototype consisting of two parents and their biological children, other groups are also recognized as falling within it, such as lone-parent families, step-families, adoptive families, and, in some subcultures, 'friends as family'. We should however not make the mistake of assuming that this categorization tells the whole story when it comes to family life - as Gillis (1996) 
argues, there are both the actual families we live with, and the idealized, symbolic and mythical families we live by.

Furthermore, categories are never fixed but undergo constant boundary changes as a result of dialogue, dispute and power struggles (Tilly, 2004; Hopkins, 2008). For example in the UK, researchers are arguing that recent demographic and lifestyle shifts have meant that the previously distinct divide between 'family' and 'friends' has become blurred, creating fluid networks of intimates and personal communities (Smart, 2007; Jamieson, Morgan, Crow and Allan, 2006; Pahl and Spencer, 2004). Nevertheless, both in common parlance and within the sociological community, the concept of 'family' remains one with considerable purchase.

Acts of categorization matter because language is never 'just words' but rather, the names and labels we give to things have real consequences in the lives of individuals (cf. Thomas, 1967). The act of placing phenomena into categories is, furthermore, never a neutral exercise. Relations of domination and subordination are reflected in the dominant narratives and discourses that are employed when positioning people into categories (Taylor, 1998), and consequently categorization can serve social purposes such as (re)creating social inequalities and boundaries between different groups of people, between 'us' and 'them' (van Dijk, 1998). For example, many of the negative connotations that are connected to the label 'lone mother' are derived from ideologies of gender, sexuality and family, which in turn have historical roots (eg, Phoenix, 1996; Roseneil and Mann, 1996; Kiernan, Land and Lewis, 1998).

These ideologies have for example been reflected in which groups of lone mothers legislation has focused on. Unmarried motherhood has historically been viewed as non-normative in Western countries, and there is a long history of legislating sex and births outside of marriage, abortion and adoption, which in turn helped shape cultural conceptions of what it meant to be a 'lone mother'. In the UK, as in most Western countries, the last century has seen a change in norms around sexuality, marriage and childbearing, as well as the liberalization of divorce law and a general rise in divorce rates, an increase in rates of cohabitation and births outside marriage, and an increase in the proportion of lone mother families (Duncan and Phillips, 2008; Office for National Statistics, 2009). At the same time, the focus of legislation has shifted from unmarried mothers to divorced mothers (eg, Kiernan et al., 1998; cf. Uttley, 2000). Thus the experience of divorce (and lone motherhood) has to some extent become normalized, as reflected in the greater acceptance of 'alternative' family forms (Duncan and Phillips, 2008).

The role of the welfare state is also crucial when considering the significance of categorizing 'lone mothers', not least because policy has such a concrete impact on the lives of lone mothers. As within legislation, the focus of social policy has shifted from unmarried mothers as a morally or psychologically deviant group to divorced mothers who are seen as a 'technical' problem (Carabine, 2001; Kiernan et al., 1998: 99; Cooke, 2009). However, as Carabine (2001) points out, the moral undertones have not completely disappeared 
from policy. For example, in the Anglo-American countries lone mothers continue to be defined as a social problem or threat because of the stereotypical view that they are perpetuating a culture of dependency or generating a social underclass (Duncan and Edwards, 1997; Roseneil and Mann, 1996; Gingrich, 2008). Thus 'categories of identity are articulated in welfare discourses' and 'inscribed in the material practices and institutional forms of welfare' (Taylor, 1998: 333), which consequently have a concrete ontological and material impact on the lives of lone mothers. There are, however, also counter-discourses that present lone mothers as strong, independent and autonomous women (eg, Renvoize, 1985), but these are in the minority and do not have the same impact or authority as the social problem and social threat discourses.

Apart from creating boundaries between differently situated individuals, the act of categorizing - such as categorizing mothers without a male partner as 'lone mothers' - tends to homogenize groups, that is, to create the illusion that members of a category share more in common than in fact they do (cf., Anthias, 1998: 564). This discursive illusion hides the variety of social positions occupied by those who are ascribed the categorical identity. Lone mothers are women of different class and ethnic backgrounds with varying understandings of what 'good' motherhood entails, and will have different routes into and experiences of lone motherhood (Duncan and Edwards, 1999). Just as there is no 'standard British family' (Duncan and Smith, 2002: 473) there is also no 'standard lone mother family'. Therefore, as Duncan and Edwards (1999: 4) argue, 'lone mother' is a taxonomic category that is not necessarily determinant of behaviour (cf. May, 2004b).

In talking about taxonomic categories, Duncan and Edwards (1999) rely on Sayer's (1992) term 'chaotic conceptions'. A chaotic conception 'arbitrarily [...] lumps together the unrelated and the inessential, thereby 'carving up' the object of study with little or no regard for its structure and form' (Sayer, 1992: 138 ), but is nevertheless given great causal explanatory power (eg, in relation to lone motherhood, that lone motherhood leads to poverty, ill health and delinquency). Duncan and Edwards (1999) further distinguish between categorical and substantive groups, categorical groups being 'taxonomic collectives' that are the result of abstractions based on 'formal relations of similarity' rather than 'actual connections' (Sayer, 1992: 101, emphasis mine), while substantive groups consist of people who have something substantive in common. According to Duncan and Edwards (1999), it is wrong to treat the categorical group 'lone mothers' as a substantive group; we cannot presume that lone mothers of different ages, classes and ethnicities behave and think similarly and share the same experiences simply because they belong to the category 'lone mother'. Sayer would call this an 'ecological fallacy', that is, making 'a spurious inference of individual characteristics from group-level characteristics' (1992: 102).

In later work, Duncan (2007) has returned to this issue, arguing that (teenage) lone mothers do not constitute a substantive group for two reasons: 
first, they do not all share the same social positions and behaviour, and second, lone motherhood is not necessarily a causal feature in their lives:

Rather, as we have seen, it is quite likely that it is membership of a particular class or ethnic group, or location in a particular area, that explains [...] how they carry out their parenting. (Duncan, 2007: 327)

Duncan and Edwards (1999: 5) recommend that researchers open the 'black box' of the category 'lone mother' by studying social differences and behaviour, as they do in their study of the gendered moral rationalities that lone mothers from different class and ethnic backgrounds apply to the question of paid employment. I propose that we go a step further to examine closely the category 'lone motherhood' itself.

\section{So is the category 'lone mother' obsolete?}

Family sociologists have long debated whether they should continue to use the concept 'family' because of concerns that by doing so they are contributing to the view that 'family' is an entity that exists 'out there' (eg, Bernardes, 1986). Similarly, it could be argued that because using the concept of 'lone mother' reifies the category, the concept should be discarded. I however maintain that because 'lone mother' is a category that has significant impact on the lives of women categorized as 'lone mothers', it remains important for sociologists to offer theoretical and practical tools to counter the social and material inequalities that many lone mothers do face. It is therefore important to be able to think of 'lone mothers' as some kind of group for pragmatic political reasons (cf. Young, 1995:188). At the same time, however, it is necessary to de-reify the category 'lone mother' by deconstructing the social processes that lie behind its definition and reproduction.

Iris Marion Young (1995: 193) has identified a similar conundrum faced by feminists in relation to the category 'woman'. While on the one hand, it is clear that women from different backgrounds and cultural contexts do not constitute a group with a shared identity, on the other hand, women, on the basis of their gender, face similar challenges and injustices. Similarly, lone mothers have been shown to face similar challenges such as risk of poverty (Bastos, Casaca, Nunes and Pereirinha, 2009) and ill health (Whitehead, Burstrom and Diderichsen, 2000). This in turn can be presented as a reason for continuing to theorize lone mothers as a group. As a way forward, Young argues for pragmatic theorizing, that is, 'categorizing, explaining, developing accounts and arguments that are tied to specific practical and political problems, where the purpose of this theoretical activity is clearly related to those problems' (Young, 1995: 192). To do so, Young (1995) adopts Sartre's concept of serial collectivity. She proposes that this allows for depicting a group of people as 
sharing a collective social position, while at the same time acknowledging that not all those who belong to this group share the same interests or a common identity (Young, 1995: 188).

If we apply this to lone motherhood, it means defining the category 'lone mother' not on the assumption that all lone mothers are 'alike', but rather on the basis of the structural conditions that categorize them as 'lone mothers'. These structural conditions include such things as family ideology that defines the two-parent family as superior; social norms around women's sexuality that place it within a (married or committed) heterosexual framework; women's position on the labour market which to an extent determines lone mothers' ability to support their children financially; and how lone mothers are defined and treated by social policy. These ideologies, social norms and practices position women who parent alone as 'lone mothers', and can both enable and constrain their action, but do not wholly determine it (Young, 1995: 205). Rather than disposing of the category 'lone mother' altogether, adopting a pragmatic approach to study how this category is (re)produced, and to what effect, makes it possible to illuminate the systematic, structured and institutional ways in which the label 'lone mother' is used and the impact this has on women's lives (cf. Young, 1995: 192).

There is also the issue of the extent to which individuals who are deemed to belong in a category actually feel that this categorization is appropriate. Adopting the concept of seriality means that it is not necessary for people to identify with a category in order for social scientists to study 'the social production and meaning of membership in collectives' (Young, 1995: 198). Thus Young distinguishes between 'group' as a self-consciously and mutually constituted collective and 'series' as a collective whose members are externally defined as such (Young, 1995: 199). In other words, to talk of seriality does not assume that all those who are categorized as members of a collectivity would choose to categorize themselves as belonging there.

This distinction between 'group' and 'series' is useful in avoiding the claim that the category 'lone mother' defines 'the person's identity in the sense of forming [...] her individual purposes, projects, and sense of self in relation to others' (Young, 1995: 202). The structures that position women in the category 'lone mother' in other words do not define individuals, but they are 'material social facts that each individual must relate to and deal with', and the ways in which individuals do so is 'infinitely variable' (Young, 1995: 206). Previous research has found that women who parent alone tend to be aware of being categorized as a 'lone mother' and to have some narrative about how appropriate the concept 'lone mother' is in describing them - whether they reject it, accept it, or try to define it in alternative ways (eg, May, 2004a; Bock, 2000). It is therefore important when studying the operations of such a social category also to include a focus on individual women's (dis)identification with the category 'lone mother'. I will now go on to discuss Brubaker and Cooper's (2000) distinction between categories of analysis and categories of practice as a further tool of pragmatic theorizing. 


\section{Categories of practice}

Brubaker and Cooper, in discussing a similar dilemma to the one posed here, that is, the inappropriateness of a concept for analytical use because of the 'blunt, flat and undifferentiated' vocabulary it offers (Brubaker and Cooper, 2000: 2), distinguish between categories of practice that are used in everyday language and categories of social analysis. Although there is often slippage between the two - for example concepts such as 'identity', 'nation' and 'ethnicity' are put to both practical and analytical uses that mutually influence each other-Brubaker and Cooper argue that the existence of the former does not necessitate the existence of the latter (Brubaker and Cooper, 2000: 4). 'Lone motherhood' is one such category of practice in everyday usage that has also uncritically been employed as a category of analysis by social scientists who have thereby unintentionally reproduced or reinforced the reification of the category 'lone motherhood' (cf Brubaker and Cooper, 2000: 5).

As a way of avoiding such reification, Brubaker and Cooper maintain that it is possible for social scientists to examine talk about and practices related to a category without positing its existence - for example, one can study 'social and political practices oriented to the presumed existence of putative 'races' [...] without positing the existence of "races" (Brubaker and Cooper, 2000: 5). I therefore argue that it is possible to examine 'lone motherhood' as a category of practice without at the same reifying it, and I propose an approach that examines the following three aspects:

- Categorization from the outside

- Situated self-understanding

- Connectedness or groupness

These represent three different facets of 'identity': being identified by others as a representative of an identity category; identifying oneself with this identity category; and feeling some form of similarity or affinity with others who are placed or who place themselves in this particular identity category.

\section{Categorization from the outside}

The first perspective, external categorisation, examines how the lives of lone mothers are affected by being structurally, as well as by other people, positioned within the category 'lone mother' (cf. Young's concept of series). As already touched upon, some sections of the population have more power to name things and to have their definition stick (Foucault, 1989). The state, for example, is a particularly powerful institution that plays a significant role in the categorisation of individuals and has the material and symbolic resources to impose its categories on non-state actors (Brubaker and Cooper, 2000: 15-16). Consequently, any analysis of the process of (re)producing categories 'must 
take account of power, how it is manifested and negotiated' (Hopkins, 2008: 365).

One of the main sites of categorization with great impact on the lives of lone mothers is indeed social policy, as discussed above (cf. Anthias, 2005; Duncan and Edwards, 1999; May, 2001). Within Anglo-American welfare states, the category 'lone mother' attributes to lone mothers essentialized (im)moral characteristics, such as 'dependent' or 'underclass', that in turn are applied to evaluate their 'genuine' needs and the legitimacy of their claims to welfare (Taylor, 1998). 'Lone motherhood' has thus become a totalising identity category that can be used in social policy discourses as a way of fixing in place or disciplining certain groups of women (Taylor, 1998). These countries also tend to employ rather draconian policies towards lone mothers such as various welfare-to-work schemes which in turn can have a negative impact on the quality of life of lone mothers (Power, 2005). In contrast, in the 'needs-based' welfare states of the Nordic countries, the explicit policy aim of enabling lone mothers to combine the financial and caring aspects of parenthood is experienced as less stigmatizing and the more generous benefits mean that lone mothers in these countries are on average financially better off and healthier than their counterparts in, say, the US and Canada (Skevik, 2005; Curtis and Phipps, 2004; May, 2001).

Much research has indeed been devoted to this issue of how states and official institutions define lone motherhood and the impact these definitions have on the lives of lone mothers. However, as Hopkins points out, it is important to recognize that debates over the meanings of identities do not take place in a rarefied public sphere but relate to everyday practice' (Hopkins, 2008: 365). It is in other words also important to examine how categorization occurs in everyday settings and in the personal networks of individuals (de Federico de la Rúa, 2007). These networks 'reflect both the macro-social historical institutional pressure of the times in which they emerge, and the micro, individual personal decisions of creating, maintaining or abandoning this or that relationship' (de Federico de la Rúa, 2007: 684, emphasis mine). It is in these personal networks and everyday social relations that abstract social categories come alive as their meanings are negotiated and contested in concrete situations. Despite clear improvements in how lone motherhood is viewed, there still remain some stigmatizing aspects to being a lone mother, which echo the ideological differentiation between 'normal' nuclear families and other, 'inadequate' families (VanEvery, 1999). Consequently, it is not surprising that lone mothers have been shown to continue to struggle with the negative way in which other people often view them (May, 2004a; McIntyre, Officer and Robinson, 2003; Bock, 2000). Hopkins (2008: 366), who argues against 'de-contextualized and sanitized' approaches, highlights the importance not only of studying everyday interactions, but also paying attention to research participants' self-understandings. It is this aspect of categorization that I now turn to. 


\section{Situated self-understanding}

Viewing lone mothers as a serial collective, the members of which are unified by external forces such as social structures or the actions of others (Young, 1995), risks depicting lone mothers as passive individuals whose lives are shaped by forces outside their control. However, members of a 'series' are not entirely passive because people rarely merely submit to the ways in which they are defined by others but rather actively engage with these definitions, as well as with shared cultural categories and understandings, in order to create their own accounts of who they are. How lone mothers negotiate the mainly negative category 'lone motherhood' and the meanings they accord it within their construction of a self is a vital component in any attempt to understand the impact that the category 'lone motherhood' has on the lives of women. This is what Brubaker and Cooper (2000) term 'self-understanding' which they define as:

a dispositional term that designates what might be called 'situated subjectivity': one's sense of who one is, of one's location, and of how (given the first two) one is prepared to act. (Brubaker and Cooper, 2000: 17)

This self-understanding is relational and contextual, that is, forged in relation to and in interaction with other people, within particular social contexts and in relation to social norms and narratives relating to the persons we 'should' be (Somers, 1994). Consequently, where a lone mother is placed (in geographical, social and ideological terms) will affect what 'lone motherhood' means to her (eg, Duncan, 2005; Rowlingson and McKay, 2005) and to what extent she will opt for or resist a 'lone mother' identity (May, 2001; Bock, 2000). Taylor's (1998) distinction between two aspects of identity, categorical identity and ontological identity, is helpful in trying to conceputalize this complexity.

Categorical identity is based on the similarities between people and is the result of an individual identifying with a social category - this would be akin to Young's (1995) self-conscious sense of belonging to a 'group' discussed below. But categorical identity is not the totality of a person, because even those people who share similarities also differ from each other. It is this difference that ontological identity, which is based on our 'deep psychological sense' of self (Taylor, 1998: 340), can grasp by highlighting what is unique and distinct about people. These two aspects of self-understanding, the categorical and the ontological, are not mutually exclusive; we create a sense of unity out of an interplay between the two. Viewing lone mothers merely through their categorical identity hides this complexity:

Dominant discourses seek to position subjects in terms of a set of ascribed characteristics which account for, or totalise identity by making those ascribed characteristics 'stand for' the complete identity of the subject. (Taylor, 1998: 348) 
In order to remedy such totalizing accounts of lone mothers, it is important to adopt a holistic perspective on an individual's life and her self-understanding that captures both the categorical and ontological dimensions of identity. One way of doing so is to utilise biographical methods (May, 2001; May, 2004a). Somers puts forward a similar argument, that is, that examining identities through 'the categorically destabilizing dimensions of time, space, and relationality' allows one 'to avoid the hazards of rigidifying aspects of identity into a misleading categorical entity’ (Somers, 1994: 606). This entails adopting a narrative approach because:

it is through narrativity that we come to know, understand, and make sense of the social world, and it is through narratives and narrativity that we constitute our social identities. (Somers, 1994: 606)

Somers points out further that a focus on ontological narrativity avoids 'categorical rigidities' because it captures how our self-understandings are 'embedded in overlapping networks of relations that shift over time and space' (Somers, 1994: 607) as well as deriving from cultural narratives that locate us within a complex network of rules, practices and institutions (Somers, 1994: 625). To infer self-understanding from merely one category is thus to oversimplify this dynamic and multidimensional process of constructing a self. A person has a range of possible narratives to hand in order to account for their identity and people tend not to employ merely one narrative but stitch together several (Reynolds et al., 2007). Our resulting identities are never smooth (eg, Reynolds et al., 2007) but rather we have many facets to ourselves, some of them contradictory (Hoggett, 2001; Bhavnani and Phoenix, 1994: 9).

Adopting a narrative biographical approach means that rather than employing 'lone motherhood' as a category of analysis, where invariably the different elements of the lone mother's life are linked to and even explained through lone motherhood, lone motherhood is placed in, and given meaning in relation to, a broader biographical perspective (May, 2004b). In a study I conducted on the life stories of Finnish lone mothers, I found that lone motherhood emerged less as a distinct family form and more as an experience coloured by the lone mother's position in a web of family relationships, as well as her place in broader personal, social and historical contexts:

A lone mother can appear as a daughter doing her best to avoid the mistakes her parents made with her, as a heart-broken woman learning to live without the father of her children, as a member of a large family network who falls upon difficult times when this network shrinks, or as a woman in a male dominated society whose lone motherhood highlights existing gender inequalities. These images help deconstruct lone motherhood as it tends to be viewed: from the outside and as a unitary category of women defined by their lack of a male partner. (May, 2004b: 401) 
Furthermore, I found that the narrators only explicitly mentioned 'lone motherhood' when discussing other people's attitudes, whereas their narrative identities were built upon narratives of 'good' motherhood, respectability, independence and family (May, 2001; May, 2004a; May, 2008). This helped the narrators counterbalance any negative judgment or avoid classification as a stereotypical 'lone mother' (cf. Skeggs, 1997). I have therefore argued that lone motherhood easily becomes a lens through which lone mothers are seen from the outside, but because it comes laden with negative connotations, lone mothers can be wary of adopting it as an identity (cf. Skeggs, 1997: 106). Thus 'lone motherhood', though often viewed as a relevant and self-explanatory identity category from the outside, does not necessarily appear as such to lone mothers themselves.

Although lone mothers do show agency by resisting some of the negative definitions that come with the category 'lone mother', it would appear to be difficult for them to 'escape' this category altogether even if they wished to do so (May, 2004a; Harrington, 2002; Bock, 2000; Duncan and Edwards, 1999; cf. Young, 1995: 201). This helps to explain the seemingly contradictory way in which some lone mothers identify with the category 'lone mother' yet at the same time distance themselves from it (May, 2004a; Bock, 2000). It would appear that just like the category 'woman', 'lone motherhood' is such a powerful category that individuals cannot avoid it completely. Consequently, whatever their views on the category 'lone mother', women who are placed within it tend to engage in a dialogue with the totalising aspects of the category when accounting for their sense of self (cf. Bock, 2000; May, 2004a; cf Taylor, 1998). This is perhaps partly because a person's self-understanding must make sense to other people (Hopkins, 2008: 365), which is why, if the category is salient enough in everyday life, even a refusal to inhabit a category does not automatically mean that it can be entirely abandoned (Skeggs, 1997: 166).

\section{Groupness}

So far I have examined how categories are imposed from the outside and negotiated by those who potentially find themselves thus categorized. There is also a further collective element to identity categories that acts as a basis for a sense of groupness (Young, 1995). I therefore argue that it is important to examine the extent to which those who identify with a category feel a sense of collective identity or 'commonality, connectedness, and groupness' (Brubaker and Cooper, 2000: 20), that is, to what extent 'lone mother' is an intentional collective category (Todd, 2005). Such a sense of groupness involves 'a sense of belonging to a distinctive, bounded group, involving both a felt solidarity or oneness with fellow group members and a felt difference from or even antipathy to specified outsiders' (Brubaker and Cooper, 2000: 19).

The problem with categorical approaches to the study of lone motherhood is that they risk depicting lone mothers as a group with similar experiences, 
values and interests, simply because one aspect of their lives (i.e., family form) fits within a specific category (Duncan and Edwards, 1999; Duncan, 2007). 'Lone motherhood' has come to stand as a proxy for experience because of the assumption that self-understanding is based on such categories (cf. Somers, 1994: 624). We cannot however take such a sense of collective identity among lone mothers as an axiomatic given (Todd, 2005; Brubaker and Cooper, 2000: 31 ), because groupness and boundedness are contingent and 'emergent properties of particular structural or conjunctural settings rather than [...] always there in some form' (Brubaker and Cooper, 2000: 28). Categorical identity can be either imposed or chosen - it is more likely to be the basis of groupness if it is chosen rather than imposed, and it is more likely to be chosen if it comes laden with positive definitions. As discussed above, many lone mothers find the category 'lone mother' problematic and therefore do not base their identities on it which, in turn, indicates that, for these individuals, it would not operate as a basis for a collective identity either. Then again, the definitions of a category are likely to shift over time and vary across social and cultural contexts, and therefore it is also to be expected that a sense of groupness will also vary across time and space (cf. Todd, 2005). The extent to which lone mothers feel such groupness, and why they either do or do not, is something that requires further empirical investigation.

\section{Conclusion}

The central question posed by this paper is how to study lone motherhood without contributing to the reification of the category 'lone mother', which tends to be viewed by both 'lay' people and social scientists as an entity that exists 'out there'. I have argued that this has negative consequences for women who are categorized as lone mothers, not least because of the negative and stigmatizing connotations associated with the category 'lone mother'. Furthermore, employing 'lone mother' as an identity category means that those who are seen to fall within the category are viewed as alike, sharing the same interests and identity. As social scientists, however, our job should be to examine critically where social categories come from, how they are constructed, to what ends and with what consequences. It is nevertheless also important to be able to continue highlighting the inequalities that exist in society, even if we remain critical of the categories that form the basis of such inequalities, categories such as 'race', 'gender' and 'lone motherhood'. The aim of this paper has therefore been to find a way of analyzing the lives of lone mothers without making totalizing claims about these women as individuals, but at the same time without depoliticizing the category 'lone mother'.

In order to do so, I have adopted Young's (1995) concept of serial collectivity. Viewing lone motherhood as a 'series' rather than a 'group' means that the focus shifts from individual lone mothers and their identity characteristics to social structures, ideologies and practices that help define women who 
parent without a male partner as 'lone mothers'. The concept of serial collectivity, however, does allow the depiction of lone mothers as some kind of group based on their shared structural location in society, which in turn makes it possible to continue to argue that they face structural inequalities.

I further employed Brubaker and Cooper's (2000) distinction between categories of analysis and categories of practice in order to engage critically with how the category 'lone mother' is used within the social sciences. I argued that 'lone motherhood' exists as a category of practice and should be studied as such, but without slipping into using 'lone mother' as a category of analysis. I identified three perspectives from which the category 'lone mother' can be studied as a category of practice: how the category 'lone motherhood' is employed and in which contexts, that is, who gets placed in it, how and by whom; how lone mothers relate their self-understanding to the category 'lone mother' and the effects that being categorized has on the everyday lives of these mothers; and the extent to which 'lone motherhood' evokes a sense of solidarity or groupness among lone mothers.

This shift from imputing a 'lone mother' identity to examining the social conditions that place these women in a serial collective and the impact this has on their lives is significant because it enables breaking the vicious circle of blaming individual lone mothers for the consequences of their social position (eg, their poverty or dependence on welfare benefits). It also challenges social scientists to provide more complex accounts of the lives of lone mothers.

\section{Acknowledgement}

I would like to thank the two anonymous reviewers for their valuable comments that significantly helped improve this paper.

\section{References}

Anthias, F., (1998), 'Evaluating 'diaspora': Beyond ethnicity?', Sociology, 32 (3): 557-580.

Anthias, F., (2005), 'Social stratification and social inequality: Models of intersectionality and identity' in Devine, F., Savage, M., Scott, J. and Crompton, R. (eds), Rethinking Class: Culture, Identities and Lifestyles, Basingstoke: Palgrave Macmillan.

Bastos, A., Casaca, S.F., Nunes, F. and Pereirinha, J., (2009), 'Women and poverty: A gendersensitive approach', Journal of Socio-Economics, 38 (5): 764-778.

Berger, P.L. and Luckmann, T., (1966), The Social Construction of Reality: A Treatise in the Sociology of Knowledge, New York, NY: Doubleday.

Bernardes, J., (1986), 'Multidimensional developmental pathways: A proposal to facilitate the conceptualisation of 'family', Sociological Review, 34 (3): 590-610.

Bhavnani, K.-K. and Phoenix, A., (1994), 'Shifting identities shifting racisms', Feminism and Psychology, 4 (2): 5-18. 
Bock, J., (2000), 'Doing the right thing? Single mothers by choice and the struggle for legitimacy', Gender and Society, 14 (1): 62-86.

Brubaker, R. and Cooper, F., (2000), 'Beyond "identity", Theory and Society, 29 (1): 1-47.

Carabine, J., (2001), 'Constituting sexuality through social policy: The case of lone motherhood 1834 and today', Social and Legal Studies, 10 (3): 291-314.

Cooke, M., (2009), 'A welfare trap?: The Duration and dynamics of social assistance use among lone mothers in Canada', Canadian Review of Sociology, 46 (3): 179-206.

Curtis, L. and Phipps, S., (2004), 'Social transfers and the health status of mothers in Norway and Canada', Social Science and Medicine, 58 (12): 2499-2507.

van Dijk, T.A., (1998), Ideology: A Multidisciplinary Approach, London: Sage.

Duncan, S., (2005), 'Mothering, class and rationality', Sociological Review, 53 (1): 50-76.

Duncan, S., (2007), 'What's the problem with teenage parents? And what's the problem with policy?' Critical Social Policy, 27 (3): 307-334.

Duncan, S. and Edwards, R., (1997), 'Single Mothers in Britain: Unsupported Workers or Mothers?' in Duncan, S. and Edwards, R. (eds), Single Mothers in an International Context: Mothers or Workers? London: UCL Press.

Duncan, S. and Edwards, R., (1999), Lone Mothers, Paid Work and Gendered Moral Rationalities, Basingstoke: Macmillan.

Duncan, S. and Phillips, M., (2008), 'New families? Tradition and change in modern relationships', in Park, A. et al., (eds), British Social Attitudes: The 24 ${ }^{\text {th }}$ Report (2007/2008 ed.), London: Sage/NatCen.

Duncan, S. and Smith, D., (2002), 'Geographies of family formations: Spatial differences and gender cultures in Britain', Transactions of the Institute of British Geographers, 27 (4): 471-493.

de Federico de la Rúa, A., (2007), 'Networks and identifications: A relational approach to social identities', International Sociology, 22 (6): 683-699.

Foucault, M., (1989), The Order of Things: An Archaeology of the Human Sciences, London: Routledge.

Gillis, J.R., (1996), A World of Their Own Making: A History of Myth and Ritual in Family Life, Oxford: Oxford University Press.

Gingrich, L.G., (2008), 'Social exclusion and double jeopardy: The management of lone mothers in the market-state social field', Social Policy and Administration, 42 (4): 379-395.

Harrington, C., (2002), 'Agency and social identity: Resistance among Pakeha New Zealand mothers', Women's Studies International Forum, 25 (1): 109-126.

Hoggett, P., (2001), 'Agency, Rationality and Social Policy', Journal of Social Policy, 30 (1): 37-56.

Hopkins, N., (2008), 'Commentary: Identity, Practice and Dialogue', Journal of Community and Applied Social Psychology, 18 (4): 363-368.

Jamieson, L., Morgan, D., Crow, G. and Allan, G., (2006), 'Friends, neighbours and distant partners: Extending or decentring family relationships?' Sociological Research Online, Volume 11, Issue 3, <http://www.socresonline.org.uk/11/3/jamieson.html $>$.

Kiernan, K., Land, H. and Lewis, J., (1998), Lone Motherhood in Twentieth-Century Britain: From Footnote to Front Page, Oxford: Clarendon Press.

Lakoff, G., (1987), Women, Fire, and Dangerous Things: What Categories Reveal about the Mind, Chicago: University of Chicago Press.

Lakoff, G. and Johnson, M.,(1999), Philosophy in the Flesh:The Embodied Mind and Its Challenge to Western Thought, New York: Basic Books.

Lakoff, G. and Johnson, M., (2003), Metaphors We Live By, Chicago, Ill: University of Chicago Press.

May, V., (2001), Lone Motherhood in Finnish Women's Life Stories: Creating Meaning in a Narrative Context, Åbo: Åbo Akademi University Press.

May, V., (2004a), 'Narrative identity and the re-conceptualization of lone motherhood', Narrative Inquiry, 14 (1): 169-189.

May, V., (2004b), 'Meanings of lone motherhood within a broader family context', Sociological Review, 52 (3): 390-403. 
May, V., (2008), 'On being a 'good' mother: The moral presentation of self', Sociology, 42 (3): 470-486.

McIntosh, M., (1996), 'Social anxieties about lone motherhood and ideologies of the family: two sides of the same coin' in Silva, E.B. (ed.), Good enough mothering? Feminist perspectives on lone motherhood, London: Routledge.

McIntyre, L., Officer, S. and Robinson, L.M., (2003), 'Feeling poor: The felt experience of lowincome lone mothers', Affilia, 18 (3): 316-331.

Office for National Statistics, (2009), Social Trends 39, London: Office for National Statistics/ Palgrave Macmillan.

Pahl, R., and Spencer, L., (2004), 'Personal communities: Not simply families of 'fate' or 'choice", Current Sociology; 52 (2): 199-221.

Phoenix, A., (1996), 'Social constructions of lone motherhood: A case of competing discourses' in Silva, E.B. (ed.), Good enough mothering? Feminist perspectives on lone motherhood, London: Routledge.

Power, E.M., (2005), 'The unfreedom of being other: Canadian lone mothers' experiences of poverty and 'life on the cheque', Sociology, 39 (4): 643-660.

Renvoize, J., (1985), Going Solo: Single Mothers by Choice, London: Routledge and Kegan Paul.

Reynolds, J., Wetherell, M. and Taylor, S., (2007), 'Choice and chance: Negotiating agency in narratives of singleness', Sociological Review, 55 (2): 331-351.

Roseneil, S. and Mann, K., (1996), 'Unpalatable choices and inadequate families: Lone mothers and the underclass debate' in Silva, E.B. (ed.), Good enough mothering? Feminist perspectives on lone motherhood, London: Routledge.

Rowlingson, K. and McKay, S., (2005), 'Lone motherhood and socio-economic disadvantage: insights from quantitative and qualitative evidence', Sociological Review, 53 (1): 30-49.

Sayer, A., (1992), Method in Social Science: A Realist Approach (2 ${ }^{\text {nd }}$ ed.), London: Routledge.

Skeggs, B., (1997), Formations of Class and Gender: Becoming Respectable, London: Sage.

Skevik, A., (2005), 'Women's citizenship in the time of activation: The case of lone mothers in "needs-based" welfare states', Social Politics, 12 (1): 42-66.

Smart, C., (2007), Personal Life: New Directions in Sociological Thinking, Cambridge: Polity.

Somers, M.R., (1994), 'The narrative constitution of identity: A relational and network approach', Theory and Society, 23 (5): 605-649.

Taylor, D., (1998), 'Social identity and social policy: Engagements with postmodern theory', Journal of Social Policy, 27 (3): 329-350.

Thomas, W.I., (1967), Social Organization and Social Personality, Chicago: University of Chicago Press.

Tilly, C., (2004), 'Social boundary mechanisms', Philosophy of the Social Sciences, 34 (2): 211-236.

Todd, J., (2005), 'Social transformation, collective categories, and identity change', Theory and Society, 34 (4): 429-463.

Uttley, S., (2000), 'Lone mothers and policy discourse in New Zealand', Journal of Social Policy, 29 (3): 441-458.

VanEvery, J., (1999), 'From modern nuclear family households to postmodern diversity? The sociological construction of "families", in Jagger, G. and Wright, C. (eds), Changing Family Values, London and New York: Routledge.

Whitehead, M., Burstrom, B. and Diderichsen, F., (2000), 'Social policies and the pathways to inequalities in health: A comparative analysis of lone mothers in Britain and Sweden', Social Science and Medicine, 50 (2): 255-270.

Young, I.M., (1995), 'Gender as seriality: Thinking about women as a social collective', in Nicholson, Linda and Seidman, Steven (eds), Social Postmodernism: Beyond Identity Politics, Cambridge: Cambridge University Press. 